\title{
Representação contra o Diretor da Saint John d'el Rey Mining Company, Limited (Morro Velho) 1861*
}

\section{Representation against the Director of the Saint John d'el Rey Mining Company, Limited (Morro Velho) 1861**}

\author{
RAFAEL DE FREITAS E SOUZA \\ Doutor em História Social/USP \\ Professor do IFSUDESTEMG - Campus Rio Pomba \\ Rua Dr. José Sebastião da Paixão $s / n^{\circ}$, Lindo Vale \\ Rio Pomba/MG, CEP 36.180-000 \\ rf.souza@bol.com.br
}

RESUMO Publicamos a seguir um documento dirigido ao Imperador dom Pedro II, em 1861, denunciando, sob o ponto de vista de um eclesiástico católico, as interferências praticadas por James Newell Gordon, superintendente da Saint John d'el Rey Mining Company, Limited (Morro Velho), nas práticas religiosas dos escravos (que à época eram quase 3000 ) e os atritos que ocorriam entre catolicismo e protestantismo dentro da companhia. Suas entrelinhas, no entanto, acabam por revelar outros importantes aspectos do mundo do trabalho na mineração aurífera inglesa em Minas Gerais, na segunda metade do século XIX, como por exemplo, os castigos, prisões, descanso dominical, assistência religiosa aos enfermos, mendicância, relações de hierarquia, dentre outros.

* Artigo recebido em: 28/09/2010. Aprovado em: 14/11/2011.

** Agradeço especialmente ao Monsenhor Flávio Carneiro Rodrigues a autorização de pesquisar a documentação referente aos Governos Episcopais. 
Palavras-chave mineração, escravidão, religião

ABSTRACT We are publishing a document sent to the Emperor of Brazil, D. Pedro II, in 1861, denouncing, under a catholic clergyman's point of view, the interferences practiced by James Newell Gordon, superintendent of Saint John d'el Rey Mining Company, Limited (Morro Velho), in the slaves' religious practices and the attritions which happened between Catholicism and Protestantism in this company. Between the lines, however, we can observe that it ends for revealing other important aspects of the world of the work in the English auriferous mining in Minas Gerais, in the second half of the century XIX, as for instance, punishments, prisons, Sunday rest, religious attendance to patients, begging, hierarchy relationships, among others.

Keywords mining, slavery, religion

\section{Comentário}

Ao contrário do que imagina o senso comum, Minas Gerais ainda guardava toneladas de ouro em seu subsolo no século XIX. No entanto, esta riqueza se encontrava nas jazidas primárias localizadas há metros, ou mesmo quilômetros, de profundidade, que o know-how português/africano do século anterior foi incapaz de atingir.

Após o franqueamento dos portos promovido pelo Príncipe Regente, dom João, na primeira década do oitocentos, faltava ainda abrir as bocas das minas aos investidores europeus - tarefa que seria realizada um pouco mais tarde por seu filho-sucessor, dom Pedro I.

A Constituição de 1824 foi omissa no que tange ao direito de propriedade do subsolo. ${ }^{1}$ Este fato implicou na permanência tácita do direito real ad inferos; ou seja, os minerais continuaram pertencendo ao rei e o sistema tributário ficou praticamente inalterado até a República. Por outro lado, a nova carta não proibiu a aquisição e exploração das minas por estrangeiros.

Face a esta lacuna, o Imperador legislava individualmente a cada nova concessão. Assim, O Decreto Imperial de 16 de setembro de 1824 autorizou, nominalmente, que o britânico, Edward Oxenford, negociante em Londres, se estabelecesse em Minas Gerais e formasse empresa. Neste ano, ele fundou a Imperial Brazilian Mining Association (Gongo Soco).

Como coroamento deste processo, a Lei Imperial, de 6 de abril de 1827 , reduziu o imposto sobre o ouro de $20 \%$ para $5 \%$. Dois anos depois, foi emitido o Decreto Imperial, de 27 de janeiro de 1829, que permitia a associação de estrangeiros e brasileiros (que não precisavam mais de

1 O inciso XXII do artigo 179 firmava apenas que: "É garantido o Direito de Propriedade em toda a sua plenitude. Se o bem publico legalmente verificado exigir o uso, e emprego da Propriedade do Cidadão, será elle préviamente indemnisado do valor della. A Lei marcará os casos, em que terá logar esta unica excepção, e dará as regras para se determinar a indemnisação". In: BRASIL. Collecção das leis do Brazil, desde a independência: 1822-1825. Ouro Preto: Typografia de Silva, 1829. 
autorização para minerar em terras de sua propriedade) para a exploração de minas no Brasil. Na sequência, diversas minas abandonadas, mas ainda ricas, foram adquiridas por companhias estrangeiras, sobretudo inglesas.

De 1824 a 1898, vinte companhias de capital estrangeiro se instalaram em Minas Gerais. Segundo Fábio Carlos da Silva, durante o século XIX os investimentos destas empresas atingiram a cifra de "dois milhões duzentas e quinze mil libras esterlinas e a produção estimada foi de 102.545 quilos". ${ }^{2}$

Servindo-se de avultado capital, maquinário moderno, administração empresarial e grande contingente de trabalhadores, estas empresas impulsionaram o segundo rush do ouro na Província dourada. Este insulamento industrial em antigas localidades reanimou o setor extrativo e provocou profundas mudanças na situação tributária, econômica, ambiental, demográfica e de poder onde se fixaram. Mas sua influência se fez sentir ainda em diferentes esferas do Estado e da Igreja Católica.

Dentre estas empresas, destaca-se a Saint John d'el Rei Mining Company, também conhecida como Mina de Morro Velho (situada na atual cidade de Nova Lima/MG). ${ }^{3}$ Adquirida pelos ingleses, em 1830, é considerada a maior, mais lucrativa e uma das mais longevas companhias auríferas estabelecidas em Minas Gerais. Foi, sem dúvida, um dos mais lucrativos empreendimentos ingleses na América Latina. Em meados do século XIX, chegou a empregar 2500 trabalhadores entre livres e escravos; nacionais e estrangeiros. Em 1917, atingiu a impressionante cifra de 3000 operário(a) s. Entre 1860 e 1893, extraiu 30.790,4 kg de ouro, equivalendo a 80,3\% da extração aurífera de Minas Gerais no período. ${ }^{4}$

No que tange ao campo confessional, estes novos empreendedores eram protestantes. Desde a primeira metade do século XIX, os ingleses haviam adquirido o direito de abrir cemitério, erigir capela e ter pastores próprios no Brasil. A Constituição de 1824, em seu artigo $5^{\circ}$, ratificou a liberdade de crença: "a religião Católica Romana continuará a ser a religião do Império. Todas as outras religiões serão permitidas com seu culto doméstico ou particularmente, em casas para isso destinadas, sem forma alguma exterior de templo". ${ }^{5}$ Por conseguinte, do ponto de vista religioso, as companhias inglesas, tornaram-se enclaves anglicanos no seio do arcebispado marianense. É natural, portanto, imaginar que tensões ocorreriam.

2 SILVA, Fábio Carlos da. Barões do ouro e aventureiros britânicos no Brasil: a companhia inglesa de Macaúbas e Cocais (1828-1912). São Paulo, Universidade de São Paulo, 1997, p.2. (História, Tese de doutorado)

3 De acordo com Waldemar de Almeida Barbosa, "o Distrito de Congonha do Sabará foi criado pela lei provincial n.50, de 8 de abril de 1836". "A freguesia de Congonha do Sabará foi elevada à categoria de vila, com a criação do município, desmembrado do de Sabará, com o decreto n.361, de 5 de fevereiro de 1891, que lhe deu o nome de Vila Nova de Lima. (...) Posteriormente, a lei n.843, de 7 de setembro de 1923, deu-lhe a denominação atual, Nova Lima". BARBOSA, Waldemar de Almeida Barbosa. Dicionário Histórico-geográfico de Minas Gerais. Belo Horizonte: Editora Saberb, 1971, p.320.

4 LIBBY, Douglas Cole. Transformação e trabalho em uma economia escravista: Minas Gerais no século XIX. São Paulo: Brasiliense, 1988, p.271.

5 BRASIL. Collecção das leis do Brazil, desde a independência: 1822-1825. 
O documento adiante transcrito é uma Representação redigida pelo capelão da citada companhia, o padre Francisco Rodrigues dos Santos Saraiva, no dia 29 de novembro de 1861 e apresentada ao chefe de polícia, por via do subdelegado do Distrito de Gongonhas do Sabará, para ser remetida ao Imperador dom Pedro II. ${ }^{6}$ Nela, Saraiva acusa o superintendente da mesma, James Newell Gordon, de cometer diversos atos de impiedade e abusos contra a religião oficial do Estado brasileiro e contra ele próprio - explícito no contraste feito entre as capelas, os cemitérios e as casas reservadas ao pastor protestante e ao padre católico. Denúncia também às ingerências praticadas por Gordon nas práticas religiosas (batismo dentro do prazo canônico e crisma) dos escravos da empresa, cujas almas estavam sob sua proteção, além do cerceamento aos direitos costumeiros, como o descanso dominical.

Tais fatos levaram-no, após um ano e três meses de serviços prestados, a rescindir, unilateralmente, o contrato assinado com a companhia, previsto para seis anos. O ordenado estipulado era de "hum conto sette centos e cincoenta mil reis" e que, por isso, segundo ele, o superintendente "traz como razão de estar o supp.te sujeito á sua fiscalisação" .

As entrelinhas deste raro documento revelam importantes aspectos do mundo do trabalho na mineração aurífera inglesa, em Minas Gerais, na segunda metade do século XIX, como, por exemplo, os castigos dispensados aos escravos, a assistência religiosa aos enfermos, a mendicância e as relações hierárquicas na mina.

Sua relevância consiste, dentre outros aspectos, por apresentar outra versão sobre a administração Gordon e da pretensa liberalidade inglesa no trato de seus escravos, descrita por Richard Burton, em sua obra Viagem do Rio de Janeiro a Morro Velho. ${ }^{8}$

O diretor ao qual o sacerdote se refere é o irlandês James Newell Gordon, que dirigiu a companhia durante 19 anos (1857-1876). Foi o manager que ocupou o segundo maior período administrativo, sendo superado apenas por George Chalmers, que ficou à frente dos trabalhos por longos

6 Na pasta onde este documento se encontra acondicionado constam outros quatro, a saber: 1) CARTA do Ministro dos Negócios do Império, José lldefonso de Souza Ramos, datada do Rio de Janeiro a 2 de janeiro de 1862 dirigida ao Bispo de Mariana solicitando informação se o padre Francisco Rodrigues dos Santos Saraiva era pároco em sua diocese; 2) CARTA do padre Francisco Rodrigues dos Santos Saraiva remetida ao Subdelegado de Congonhas através da qual solicita que este intime ao citado diretor da companhia de Morro Velho para informar-lhe de sua demissão; 3) CARTA do padre Francisco Rodrigues dos Santos Saraiva dirigida ao Bispo de Mariana, datada de 21 de dezembro de 1861, informando-Ihe de sua demissão da companhia na qual relata brevemente parte das atitudes do citado diretor. Nela, denuncia também o reverendo de sua antiga freguesia que "a troco do dinheiro dos ingleses, é conivente com elles, e até parcial de suas iniqüidades!" Por fim, comunica-lhe de sua partida para a Europa; 4) RESPOSTA do padre Francisco Rodrigues dos Santos Saraiva dirigida ao subdelegado de polícia de Congonhas na qual refuta os argumentos apresentados no "requerimento justificativo" redigido por James Newell Gordon em resposta à petição demissionária, de 23 de novembro de 1861.

7 Arquivo Eclesiástico da Arquidiocese de Mariana. (AEAM). Governos Episcopais. Arquivo 3, gav.2, pasta 16, doc.4, f.8.

8 BURTON, Richard Francis. Viagem do Rio de Janeiro a Morro Velho. Apresentação e notas de Mário Guimarães Ferri; tradução de David Jardim Junior. Belo Horizonte/São Paulo: Ed. Itatiaia/Edusp, 1976. 
40 anos (1884-1924). ${ }^{9}$ Em 1873, Gordon ocupou o cargo de vice-cônsul britânico em Sabará. ${ }^{10}$

Foi durante sua gestão, em 1867, que a companhia recebeu a visita do inglês Richard Francis Burton. No dia 22 de novembro deste mesmo ano, ocorreu um dos maiores e mais trágicos acidentes de trabalho nesta mina. Voltaremos a este assunto adiante.

O queixoso é o presbítero secular Francisco Rodrigues dos Santos Saraiva (1834-1900). Natural do Douro, era filho de rabino espanhol da Síria convertido. Foi instruído por seu pai nas línguas semíticas (árabe e hebraico); conhecedor também do sânscrito, siríaco, grego, fenício, idiomas do norte da Europa e tinha noções de chinês; estudioso de mineralogia, botânica, história, numismática e paleografia; notável latinista, teólogo, filólogo, filósofo, poeta e dicionarista; autor do Novíssimo diccionário latino-portuguez, etymológico, prosodico, historico, geographico, mythologico, biographico (Havre, 1881) com 297 páginas in-folio. Em 1864 (três anos depois de sua queixa), tornou-se "vigário em São Francisco de Paula, no Rio Grande do Sul, onde fez collecções mineralógicas e investigações botânicas." "11 Voltou para Lisboa e, depois, retornou ao Rio de Janeiro a convite do Imperador para uma conferência que durou duas horas. Do Rio, foi para Santa Catarina onde ficou conhecido como o misterioso. O jornal Diário de Notícias do Rio de Janeiro de 15 de janeiro de 1887 assim se pronunciou sobre ele:

Da erudição moderna salta para a antiga; compulsa todas as línguas e autores; compara os homens, as civilizações, as épocas. É como uma encyclopedia viva, raciocinadora, vendo tudo das serenas regiões do espírito e lançando a sua nota particular com o sorriso de Cervantes e Rabelais, que lhe para sempre nos lábios. ${ }^{12}$

Trata-se, portanto, de um sacerdote com perfil muito superior ao comum dos clérigos que assistiam em Minas Gerais, na segunda metade do século $\mathrm{XIX}$, que causavam variados dissabores ao bispo de Mariana e com os quais a própria Saint John d'el Rey Mining Company não gostava de se relacionar.

A primeira postura a ser adotada diante de um documento de natureza acusatória é substituir a pergunta do juiz: É verdade que? pela do historiador: Será possível que? Por se tratar de uma denúncia dirigida ao Imperador dom Pedro II é, juridicamente, um ponto de vista. Vale lembrar que na pas-

9 EAKIN, Marshall C. British enterprise in Brazil: The St. John d'el Rey Mining Company and the Morro Velho Gold Mine (1830-1960). Durham and London: Duke University Press, 1989, Appendix 4 - Superintendents, St. John d'el Rey Mining Company, Limited, 1830-1960, p.273.

$10 \mathrm{Em}$ setembro deste ano, Gordon obteve do governo imperial brasileiro a ampliação a toda a província de Minas Gerais a jurisdição do distrito do Vice-consulado da Grã-Bretanha estabelecido na cidade de Sabará. Cf. Arquivo Público Mineiro. (APM). SG 28. Seção Provincial e Estadual. Fundo Secretaria do Governo. Registro de Correspondência referente à agricultura, indústria, mineração, ao comercio e a pesos e medidas (1872-1875), f.23 e segs. e 27.

11 BLAKE, Augusto Victorino Alves Sacramento. Diccionario bibliographico brazileiro. Rio de Janeiro: Imprensa Nacional, 1885. Edição do Conselho Federal de Cultura, 1970, v.3, p.106.

12 BLAKE, Augusto Victorino Alves Sacramento. Diccionario bibliographico brazileiro, v.3, p.106. 
ta onde esta Representação se encontra arquivada não há a outra versão dos fatos, ou seja, a defesa sob a ótica do diretor da companhia, embora o "requerimento justificativo" tenha sido apresentado pelo próprio Gordon ao mesmo subdelegado do Distrito de Congonhas.

Concatenando esta carta-denúncia com outros documentos existentes sobre a história da Saint John d'el Rei Mining Company, como processos judiciais e os relatórios dos Presidentes da Província, podemos indagar se as acusações feitas pelo sacerdote teriam algum fundamento parcial ou integral ou não passariam de calúnias. Embora a inculpação seja dirigida especificamente a um administrador, ela pode revelar uma tendência da companhia de constituir-se um Estado dentro de um Estado?

Antes de qualquer posicionamento, é preciso conhecer a companhia por dentro: as relações de poder e hierarquias internas, a composição da mão-de-obra, as precárias condições de trabalho e a vida dos mineiros, os desafios de administrar uma empresa deste gigantismo, bem como os embates que havia entre catolicismo e protestantismo em Minas Gerais, na segunda metade do século XIX.

A origem do problema talvez resida no seguinte conflito: a companhia, por ser propriedade inglesa, era administrada por protestantes (o documento é bastante genérico a este respeito); no entanto, seu quadro funcional era composto, majoritariamente, por trabalhadores (nacionais e estrangeiros; livres e escravos), cuja confissão religiosa oficial da maioria era o catolicismo e que necessitavam de auxílio espiritual no exercício de um trabalho marcado pelas duras condições, insalubridade e constante risco de morte.

Enquanto os ingleses tinham garantido por lei o direito à liberdade de culto e de enterrarem seus mortos em cemitérios próprios, sabiam que o catolicismo era a religião oficial do Estado. Mas, sob o ponto de vista de Gordon, dentro de uma companhia oficialmente protestante, a religião católica que era o culto tolerado. Por isso, enquanto superintendente que contratou o sacerdote e pagava-Ihe o salário, via-se no direito de tutelá-lo, assim como fazia com os escravos e todos os trabalhadores livres da mina. Porém, padre Francisco, enquanto legítimo representante da Igreja Católica, não se via como um funcionário qualquer e nem aceitava ser controlado por um protestante.

Os atritos entre o diretor e o clérigo surgiram desde sua chegada à companhia, quando Gordon se recusou a conceder sustento para seu animal: "como o dá aos empregados de primeira ordem"; por ter proibido sua ida a Sabará no dia solicitado sem indicar outro dia alternativo; e, desde 1860, não havia the fornecido uma residência digna conforme previsto no $30^{\circ}$ artigo do contrato. O sacerdote diz ainda que os próprios empregados ingleses consideravam Gordon "estouvado e insuportável". ${ }^{13}$

13 AEAM. Governos Episcopais. Arq.3, gav.2, pasta 16, doc.4, f.3v. 
Vendo-se obrigado a prover a alimentação de seu animal, ser cerceado no direito de ir e vir como se fosse um simples mineiro ou, pior, um escravo, e a falta de uma moradia condigna à altura de sua função e formação significaram para o presbítero o rebaixamento de seu status ou, em suas palavras, da "honra da dignidade Sacerdotal", como ele mesmo afirmou.

Padre Francisco acusa então Gordon de ter cometido diversos atos de impiedade contra ele próprio e contra o livre exercício da fé católica pelos escravos: chegou a prender a Manuel da Tenda "dois dias e duas noites no tronco" por ter desobedecido à ordem de não comparecer à crisma; por inveja consentia "que de pia de água benta sirva uma panella, de caldeirinha um frasco de mostarda em conserva, de galhetas um vidro d'agua de colônia, de campainha um chocalho quebrado". Gordon não consentia que se entrasse em Morro Velho "a pedir aos fieis catholicos esmola para a Missa que na capella do Rosário se celebra todos os domingos, mandando ameaçar de pontapés os que alli se apresentarem" e, por fim, deixava "que alguns defuntos fossem dados á sepultura, sem que o capellão fosse informado, para Ihes fazer os officios eclesiásticos". ${ }^{14}$

É igualmente possível que a dedicação do padre Francisco também tenha incomodado a Gordon. Se acreditarmos nas palavras do sacerdote, ele:

Celebrava, ensinava doutrina christã, cathequisava, visitava os escravos em suas moradas uma vez por semana, administrava aos mesmos escravos a parte espiritual, encommendava os defuntos, fôra sempre ao hospital ouvir de confissão os enfermos (...) nunca se negava, apesar de serem estas ultimas coisas alheias ás suas obrigações de capellão, por não se acharem estipuladas em seu contrato e por serem attribuições parochiaes, e por cujos officios nunca o supp.te cobrara um real. ${ }^{15}$

Quando Richard Burton visitou a mina de Morro Velho, em 1867, seis anos depois da denúncia de padre Francisco, o estado precário das alfaias da igreja católica de Morro Velho continuava o mesmo. Diz ele:

Minha esposa ficou muito escandalizada, ao ver que faltava a pedra do altar; a igreja, porém, não fora consagrada, e há algo chamado "communier en blanc'. Os ornamentos não são ricos, o ostensório não passa de uma caixa de relógio com raios metálicos e há certa necessidade de 'um balde com hissope para aspersão da igreja e para guardar água benta'. ${ }^{16}$

Até que ponto a responsabilidade por este desleixo, que vinha desde 1861, deve ser atribuída a Gordon? O mesmo Burton insinua que o "sacristão preto" Antônio Marcos havia comentado que "em cada telhado de capela há um buraco pelo qual a 'pinga' cai diretamente na algibeira do padre."

14 AEAM. Governos Episcopais. Arq.3, gav.2, pasta 16, doc.4, f.7 e segs.

15 AEAM. Governos Episcopais. Arq.3, gav.2, pasta 16, doc.4, f. 9v.

16 BURTON, Richard Francis. Viagem do Rio de Janeiro a Morro Velho, p.197. 
Isto, após ter relatado a "cena pouco decorosa" da coleta de moedas de cobre na missa, oportunamente realizada no dia seguinte ao pagamento dos mineiros. ${ }^{17}$ Que destino era dado ao dinheiro desta coleta aparentemente significativa? Por que não era empregado no melhoramento interno da capela?

Até que ponto também o caráter "estouvado e insuportável" de Gordon não estaria adequado ao perfil ideal que um superintendente de mina inglesa instalada no interior do Brasil, na segunda metade do século XIX, deveria ter? Para Burton,

o superintendente deverá estar investido dos poderes absolutos de um coronel, que comanda um regimento francês, não inglês, e recebe informações diárias de seus oficiais, em vez de reuni-los para consultá-los; deverá ter autoridade para fazer e desfazer os subalternos, e estar disposto a assumir plena responsabilidade de seus atos. O subalterno pode ter permissão de encaminhar-lhe queixa contra seus superiores, mas, se tais reclamações forem infundadas, deverá ser demitido imediatamente. ${ }^{18}$

Esta posição de Burton assemelha-se àquela preconizada pelo Dr. Collins, em 1830, para a administração das plantations inglesas na América. Diz ele:

A profissão de um administrador requer a experiência de muitos anos, além de uma boa dose de sagacidade e moderação; toda escravaria é uma comunidade, e a pessoa que a comanda um déspota que exerce as funções diversas de administrador, médico e juiz, de cuja sentença não há apelação. Eu pouco conheço uma posição com tamanha responsabilidade, ou que demande habilidades mais vastas, quanto esta. ${ }^{19}$

Comandar um empreendimento com o gigantismo da Mina de Morro Velho, composto por mais de 2 mil trabalhadores livres e escravos (em 1867, eram 2.521 entre europeus, brasileiros e negros), entre os quais havia também homens de caráter duvidoso, índole violenta, alcoólatras e assassinos, não era tarefa fácil. Dirigir homens embrutecidos pelo trabalho árduo, perigoso e malsão, que a cada dia se deparavam com a morte, exigia do diretor a postura firme, decidida e irretratável diante de situações que pudessem prejudicar o bom andamento das tarefas ou em momentos onde sua autoridade fosse colocada em dúvida.

Acrescente-se ainda que Gordon substituiu Mr. Thomas Walker, que, nas palavras de Burton, era "simpático e honrado, temia responsabilidade e confiou demasiadamente nos outros; assim, como era de se esperar, sua

17 BURTON, Richard Francis. Viagem do Rio de Janeiro a Morro Velho, p.198.

18 BURTON, Richard Francis. Viagem do Rio de Janeiro a Morro Velho, p.202 e segs.

19 Dr. Collins. Practical rules for the management and medical treatment of negro slaves in the sugar colonies, 1830. Citado por MARQUESE, Rafael de Bivar. Feitores do corpo, missionários da mente: senhores, letrados e o controle dos escravos nas Américas, 1660-1860. São Paulo: Companhia das Letras, 2004, p.9 e segs. 
gestão não constituiu um sucesso". ${ }^{20}$ Por isso, é provável que a administração Gordon estivesse passando por um processo de reestruturação e redefinição hierárquica que exigia dele posturas mais enérgicas.

Enquanto protestante, é presumível que Gordon nutrisse forte intolerância frente às manifestações católicas, vistas por ele como supersticiosas e inócuas à salvação, sobretudo aquelas que pudessem interferir no bom andamento dos trabalhos, como os feriados de dias santos.

Burton admite que na gestão de Gordon havia distribuição tanto de prêmios como de punições aos negros, como multas, proibição de vender a produção de animais e verduras, prisão, agrilhoamento dos fugitivos, uso da palmatória e o açoite (antes ordenado por qualquer chefe, depois somente pelo superintendente) - esta última punição era ministrada, segundo o autor, somente em caso de embriaguez contumaz, desobediência de ordens, insubordinação ou roubo. Embora Burton reconheça essas práticas, acrescenta sempre um lenitivo.

Burton expressa um ponto de vista semelhante ao de Tácito, que somente tece comentários positivos sobre a conduta dos escravos quando estes demonstram lealdade (fides). ${ }^{21}$ Diz ele: a "conduta bem educada e respeitosa dos negros de Morro Velho que, invariavelmente tiram o chapéu para um branco estranho e estendem a mão, pedindo a benção" associada ao fato de não serem "nem imprudentes, nem demasiadamente humildes, nem grosseiros" são as melhores provas "de que são bem e justamente tratados". 22

Note que Gordon, segundo a Representação do padre Francisco, ameaçou deter os escravos que comparecessem à cerimônia da crisma e que chegou a prender um homem livre (provavelmente um ex-escravo) "dois dias e duas noites no tronco", por ter desobedecido à ordem de não comparecer à crisma, o que era especialmente escandaloso. Logo, estas práticas restritivas faziam parte da rotina administrativa em Morro Velho há muitos anos.

Sendo assim, é possível que os poderes absolutos de que Gordon necessitava e sua aversão ao catolicismo, realmente, o tenham levado a interferir na livre prática do catolicismo nas dependências da companhia e, até mesmo, cercear a liberdade de um homem livre por desobediência. Atos que, aos olhos do padre Francisco Rodrigues, eram motivados por inveja e abuso de poder.

Portanto, o juízo de Burton sobre o tratamento excepcionalmente humano que os escravos recebiam em Morro Velho precisa ser reavaliado. Embora ali os escravos gozassem de muitos direitos, a denúncia do padre

20 BURTON, Richard Francis. Viagem do Rio de Janeiro a Morro Velho, p.202.

21 JOLY, Fábio Duarte. Tácito e a metáfora da escravidão: um estudo da cultura política romana. São Paulo: Edusp 2004, p.70.

22 BURTON, Richard Francis. Viagem do Rio de Janeiro a Morro Velho, p.237. 
Francisco não deve ser descartada no que tange ao duro tratamento a eles dispensado durante a administração de Gordon, seja por exigência administrativa ou por intolerância religiosa.

É provável que Burton não tenha sido informado sobre estes fatos, ocorridos seis anos antes de sua visita, pois os ingleses, habitualmente, maquiavam o local de trabalho quando recebiam visitantes. Além disso, as informações que obteve partiram de pessoas que não tinham isenção de interesses, embora Burton não fosse ingênuo e conhecesse muito bem o esquema que mantinha a lucratividade das minas inglesas.

A trajetória administrativa de Gordon é marcada também por episódios suspeitos de lisura. Douglas Cole Libby mostrou que, em 1844, a Saint John d'el Rey Mining Company celebrou um contrato com outra empresa aurífera britânica, a Brazilian Company (Cata Branca/MG), para o aluguel de 385 escravos. O contrato previa a libertação dos cativos após 14 anos de serviços e a emancipação de seus filhos aos 21 anos de idade. No entanto, em 1859, durante a administração Gordon, o contrato foi renovado. Neste ano, a Brazilian Company dependia totalmente desta renda, embora o representante alegasse que a súbita emancipação seria "uma medida inteiramente desaconselhável [...] particularmente com referência ao bem-estar dos próprios negros". Esta renovação do contrato gerou uma série de denúncias feitas pelo deputado Joaquim Nabuco, em 1879, e expôs a Saint John a um escândalo internacional. Parte dos escravos moveu um processo contra a companhia e conquistou sua libertação por ordem do Supremo Tribunal Federal, em 1881. ${ }^{23}$

Fábio Carlos da Silva, embora não explicite a natureza da transação, revela que em 1865 Penicock Brown, da Brazilian Company, "realizou negócios ilícitos de comum acordo com seu cunhado James Gordon no que tange ao aluguel de 237 escravos (sendo 112 homens, 99 mulheres e 26 crianças) da National Brazilian". ${ }^{24}$ Esta, situada em Barão de Cocais/MG.

Outro acontecimento evidencia que o tentacular poder de Gordon atingia as secretarias do governo provincial. Douglas Libby registrou que, por volta de 1869-70, ele exerceu forte pressão para que a nova estrada que iria ligar a cidade de Queluz (hoje, Conselheiro Lafaiete) a Sabará passasse por Morro Velho. Porém, o benefício não se resumiria a esta vantagem infra-estrutural. Coube ao Estado alugar à companhia inglesa os escravos usados na abertura da via. O autor suspeita que o número de alugados deva ter sido muito grande, indicando que "subsidiada pelos cofres provinciais, a companhia logrou manter em reserva uma considerável parcela de sua força cativa, inclusive muitos escravos sob contratos de aluguel prolongados". Tamanho privilégio fez com que o deputado Cezario Gama bradasse

23 Citado por LIBBY, Douglas Cole. Transformação e trabalho em uma economia escravista, p.343.

24 SILVA, Fábio Carlos da. Barões do ouro e aventureiros britânicos no Brasil: a companhia inglesa de Macaúbas e Cocais (1828-1912). São Paulo, USP, 1997, p.108. (História, Tese de doutorado) 
na sessão extraordinária, de 7 de novembro de 1877: "O poderoso superintendente dessa companhia (...) prevaleceu-se de sua influência para, á custa da pobre província, dar emprego a braços ociosos da companhia". ${ }^{25}$

Por conseguinte, fica claro que Gordon também deixou sua consciência sepultada no Atlântico ao vir para Minas, ignorou a Lei Lord Brougham, de $1843^{26}$ e serviu-se largamente do trabalho escravo (mesmo que alugado), além de pressionar o Estado no intuito de obter vantagens para a companhia que administrava.

Burton parece estar bem posicionado para refutar toda denúncia que, segundo ele, o caluniador "que desejava promover seu próprio nome" ou o empregado demitido [seria uma alusão ao padre Francisco?] "que queria vingar-se estimulavam o preconceito popular, e insistiam, untuosamente, nas 'adinâmicas condições' do trabalhador negro e em seu tratamento 'cruel e sanguinário' pelos brancos". ${ }^{27}$

Cabe acrescentar ainda que Burton, por nacionalismo, diplomacia, gratidão pessoal ou propaganda empresarial, foi muito lisonjeiro com seu anfitrião, ocultando qualquer fato que manchasse a reputação da Saint John d'el Rey Mining Company na Europa que, segundo ele, estava "vivendo seus grandes dias". Avaliações positivas sobre a saúde financeira das companhias inglesas no exterior elevavam sua cotação na bolsa de valores de Londres.

Quanto ao acidente de 22 de novembro de 1867, anteriormente citado, cabem algumas palavras. A história da mina de Morro Velho é marcada também por suas péssimas condições de trabalho devido às longas jornadas de trabalho, insalubridade (doenças infecto-contagiosas e ocupacionais) e periculosidade pelos constantes desabamentos e outras formas de sinistros. O desastre de 1867 vitimou 21 escravos e um mineiro inglês: "onde trabaIhava áquella mesma hora mais de uma centena de operarios (...) outras [pessoas] sobreviveram mutiladas para maior infortúnio". ${ }^{28}$

Note que, até a visita de Burton, em meados daquele ano, Gordon "jamais se aventurara antes descer debaixo da terra". ${ }^{29}$ Este distanciamento físico do local de trabalho servia para reforçar a diferença de status existente

25 Annaes da Assembléia Provincial de Minas Geraes. Segundo Annno da Vigésima-segunda Legislatura. Sessão de 1877, Ouro Preto, Typ. J. F. da Paula Castro, 1877, p. 246. Citado por LIBBY, Douglas Cole. Transformação e trabalho em uma economia escravista, p.341. De acordo com o relatório do senador Joaquim Floriano de Godoy, a companhia recebeu em 1872 o pagamento de 26.371\$130 "pelas despesas feitas com a estrada de ferro de Sabará a Queluz" - Cf. Relatório com que o Exm. Sr. Senador Joaquim Floriano de Godoy no dia 15 de janeiro de 1873 passou a administração da Província de Minas Geraes ao $2^{\circ}$ Vice-Presidente Exm. Sr. Dr. Francisco Leite da Costa Belém por occasião de retirar-se para tomas assento na Câmara vitalícia. Ouro Preto, 1873, p.10.

26 Através dela, os britânicos estavam proibidos de participar do comércio negreiro. Isto impedia-lhes a compra venda e posse de cativos.

27 BURTON, Richard Francis. Viagem do Rio de Janeiro a Morro Velho, p.234

28 Revista do Arquivo Público Mineiro. Belo Horizonte: Imprensa Official de Minas Geraes, p.345, Anno VI. Fascículo II, abril a junho de 1901. O Relatório do Presidente da Província de Minas Gerais de 1868 informa que ocorreram apenas 18 mortes (1 inglês e 17 escravos). Cf. Relatório que à Assembléa Legislativa Provincial de Minas Geraes apresentou na sessão ordinaria de 1868 o Presidente da Província José da Costa Machado de Souza. Ouro Preto: Typ. de J. F. de Paula Castro, 1868. Annexo n.2. Secretaria de Policia em Minas, 26 de abril de 1868, p.5.

29 BURTON, Richard Francis. Viagem do Rio de Janeiro a Morro Velho, p.213. 
entre os trabalhadores, os feitores e o próprio Gordon que ocupava o mais elevado cargo da chefatura. Por outro lado, este afastamento dos perigos do mundo subterrâneo podia ser entendido pelos mineiros como descaso e falta de coragem - o mais importante valor dentre a ética de trabalho dos mineiros. ${ }^{30}$

Embora sejam evidentes as péssimas condições de segurança no subsolo, desconhecemos os reais fatores que provocaram o incidente. A causa pode ter sido tanto sabotagem quanto por combustão das madeiras do escoramento (quando da visita de Burton à mina, a iluminação era feita com velas e tochas), além de outras causas. Por outro lado, não se pode negar que a negligência sempre foi uma das principais razões dos acidentes de trabalho nas minas. Se o sucesso financeiro da companhia é atribuído ao superintendente, com os infortúnios não pode ser diferente.

\section{Transcrição ${ }^{31}$}

"Representação/copia/a

Sua M. I.

Documento N. 5

Com o mais profundo respeito, e com a maior magoa no coração, sou obrigado, por honra da dignidade Sacerdotal, e pela dignidade do Imperio, a levar ao alto Conhecimento de Vossa Magestade Imperial, como zeloso defensor das Leis do Estado, e da Crença, que temos a dita de professar, a verdade, assaz conhecida de todos nesta localidade, dos factos escandalosos, e inqualificaveis, que todos os dias estão succedendo na Companhia inglesa de Mineração de S. João d'El Rei, em Morro Velho.

Além de que o Culto Catholico n'esta Companhia tem antes o caracter de tolerado, e o protestante de dominante, sendo assim contrariado o Art. $5^{\circ}$ do Tit. $1^{\circ}$ da constituição Política do Brasil, abusando o Director em Morro Velho dos poderes administrativos, que a Directoria de Londres the há confiado, e depois de me haver sempre opposto em vão ás pretenções hostis, que o dicto Director desprega contra o Culto, de que sou Ministro, e contra a auctoridade espiritual, que o Prelado d'esta Diocese delegara na pessoa do Capellão, a respeito dos Súbditos Catholicos ao serviço d'esta Companhia, negando-se-lhe até o mesmo titulo de Capellão, consignado em suas Provisões, e tendo-o na conta d'um Padre assalariado, para fazer o que o mesmo Director lhe quiser ordenar, do que é prova ter eu exigido d'elle vista da Licença concessionária da Capella, a fim de me conformar

30 Há duas obras de ficção que retratam o trabalho na mina e que frisam a importância do comportamento destemido dos superiores. Veja ZOLA, Émile. Germinal. Trad. Francisco Bittemcourt. São Paulo: Abril Cultural, 1981. Para o caso da Mina de Morro Velho, consulte FOSCOLO, Avelino. Morro Velho. Edição, apresentação e notas Letícia Malard e José Américo Miranda. Belo Horizonte: UFMG, 1999.

31 Fonte: AEAM. Governos Episcopais. Arq.3, gav.2, pasta 16. 
com as determinações do Prelado, e por elle ter me ella sido absolutamente negada; no dia 22 do corrente, tendo-me mandado ordem de appresentar-me, a certas horas, no Escriptorio da Companhia, ahi compareci, vestido dos hábitos, que convem ao meu caracter, onde o dicto Director se achava, assistido de dois ingleses, empregados da mesma Companhia; e, como principiasse a interrogar-me d'um modo hostil, e desattencioso, sobre objetos da minha privativa competencia, e que tendiam a cumprir ordens do meu Excelentissimo Prelado, dando-me por offendido, e tendo por insultante contra a dignidade Sacerdotal e Episcopal similhante procedimento, por honra de meu estado quis me retirar daquelle logar, do que fui violentamente prohibido pelo dicto Director, fechando a porta por dentro, e apoderando-se da chave, como que ameaçando-me de sôcos, sem respeito, ao menos, ao meu caracter; e as vestes clericas que trajava; de sorte que, pelo sitio retirado, nenhum auxilio poderia obter no caso de alguma violencia, de que estive imminentemente ameaçado por elle, e só depois de largo espaço de tempo, á força de pedir que se me restituisse a liberdade - que se me abrisse a porta, é que ella me foi aberta, cobrindo-se-me d'insultos, na esperança da impunidade, longe de árbitros, menos os dois empregados, seus cooperadores.

Concedeu-me o Excellentissimo Prelado d'esta Diocese, quando em Julho do presente anno aqui esteve de visita, a faculdade de administrar o Sacramento da Confirmação aos Catholicos no serviço d'esta Companhia; tendo eu annunciado á Estação da Missa conventual, no Domingo, 17 do corrente, que este acto religioso teria logar no futuro Domingo, 24 do mesmo, d'entre tantos escravos por Chrismar, e que já se achavam dispostos, o Director prohibiu, que um só Chrismando comparecesse na Capella para este fim, pondo até guardas, para melhor a effecturar, e mandando encerrar na prisão da Companhia os que se oppunham a este intento injusto, e verdadeiramente escandaloso; de forma que um só Chrismando, livre, independente do Director, poude appresentar-se á recepção d'este Sacramento, causando nos fieis Catholicos, assim livres, como escravos, um descontentamento geral, e quase uma indignação, cujas conseqüências podiam, e podem ainda ser serias ao serviço desta companhia.

Senhor, os escravos, que são para cima de mil e quinhentos, sob o fanatismo protestante, não são livres no exercício da sua Religião; as suas devoções são-lhes maliciosamente frustradas, e prohibidas sob motivos especissos (sic) e a grande parte d'elles não se lhes permitte cumprir com o primeiro, e mais sagrado dos deveres, o de ouvir Missa nos Domingos, por outro escândalo, não menos inqualificavel, o de serem obrigados aos mesmos trabalhos Semanaes, quando elles, neste dia, são rigorosamente vedados aos fieis pelas leis do Creador, e da Egreja; e quanto aos mais dias sanctificados, que as Leis do Imperio respeitam, e guardam, nesta Companhia estrangeira, são tidos, como se o não foram, e os fieis Ca- 
tholicos são obrigados, apesar sem a consideral-os exteriormente, como senão existissem".

O Director d'esta companhia, como protestante que é, pretende calcar aos pés as Leis do Imperio, e a Crença, de que é inimigo figadal, humilhando-a quanto no poder d'elle está; desapeando-a daquelle lustre e elevado caracter, só próprios da verdadeira Religião, hostilisando-a em si mesmo, nos fieis, que a professam e em seus Ministros, na pessoa do Capellão, que elle tenta reduzir ao extremo da degradação. É bem lastimoso, Senhor, o contraste, que as coisas religiosas protestantes d'esta Companhia formam com as Catholicas!

É uma dor bem pungente ver, que um protestante, que está gosando de toda a proteção das Leis do Imperio, e das Auctoridades, avilte de tal arte, e até agora impunemente aquella generosa Mãi, que agasalha em seu seio! É triste, e bem triste ver os escravos d'esta Companhia queixarem-se de se verem tambem escravisados em suas consciencias, não podendo cumprir as determinações, e observar os salutares preceitos da Sancta Madre Egreja, não se Ihes permitindo, por exemplo, baptisar seus filhos se não depois de quatro, cinco, seis, e mais meses, quando aos oito dias eram obrigados a fase-lo, ou pelo muito, aos quinze, havendo causa justa; e o Capellão Catholico, Ministro da sua Crença, e como que em delegado do Prelado, não poder ter voz activa sobre os negócios catholicos entre protestantes, quaes são os Directores d'esta Companhia; e mais empregados. É triste, Senhor, e bem triste!

Mas quando, n'esta Companhia, a Bandeira Imperial Brasileira é publicamente ultrajada pelo actual Director a ponto de ter causado a indignação dos Nacionaes, e as justas bem merecidas censuras dos homens sensatos, dando elle sempre o logar mais honroso á inglesa, não admira que ultraje com mais affinco ainda aquella, de que se tem feito ostentar inimigo declarado.

Houve n'esta Companhia um Director Catholico Irlandez, que ao retirar-se d'este emprego, deixara quase concluída uma Capella Catholica, a qual foi cheia de carvão e inutilisada para sempre pelo actual Director, consintindo, apesar das muitas reiteradas reclamações, que os Mysterios da nossa Religião sejam celebrados em um quarto, pertença da cosinha dos Negros, e sob o mesmo telhado d'um morador protestante, e cujo recinto exterior serviu, e está servindo de estendedouro das roupas immundas, que saem das Minas, e de coisa mais degradante para este logar respeitável, e sem forma alguma externa de Templo, ao passo que a Egreja protestante se ostenta, como rainha a par d'uma escrava. O Cemiterio Catholico é um espaço de mato natural, exposto a pastagem de animaes, que verdadeiramente o é quasi sempre; e para mais sensível, e doloroso contraste fica parallelo ao protestante, que comparativamente é um jardim, para o qual não ha poupar trabalho, nem primor; e finalmente a residencia do Capellão 
Catholico, apesar de se the prometter em contracto uma casa decente, e commoda, é um único quarto, concedido no hospital, que fôra dos Negros, apar d'uma pomposa morada, que o Padre protestante habita; e é, para assim degradarem a Religião Cahtolica na pessoa de um Ministro, que mandaram vir da Europa um Sacerdote, sob o pretexto de não poderem aturar os Brasileiros. Mas, Imperial Senhor, apesar de estrangeiro, que sou n'esta terra, Confio na piedade, e justiça de Vossa Magestade Imperial, que como benigno Pae, protector da Nossa Sancta Crença, defensor da honra e dignidade do Imperio,e conservador da entegridade das Leis, tomará em Sua alta Consideração as medidas, que Julgar de Direito e Justiça.

Morro Velho

29 de 9bro. de 1861

Deos Guarde a Vossa Magestade Imperial por largos annos, para felicidade, lustre e gloria d'este Imperio

O Capellão Catholico da Companhia de Mineração

De S. João d'El Rei, em Morro Velho.

Francisco Rodrigues dos Santos Saraiva" 